\title{
Should The SEC Adopt International Financial Reporting Standards?
}

\author{
Clemense Ehoff Jr., Kean University, USA
}

Dov Fischer, Kean University, USA

\begin{abstract}
In 2002, the Financial Accounting Standards Board (FASB) and the International Accounting Standards Board (IASB) formally began a process to converge Generally Accepted Accounting Principles (GAAP) and International Financial Reporting Standards (IFRS). By the end of 2011, the SEC will likely decide on whether to adopt International Financial Reporting Standards as the financial reporting system for U.S. public companies, continue with the convergence project, or reject IFRS altogether. This paper examines the benefits and drawbacks of each option and formulates a recommendation as to which option is in the best interest of U.S. investors.
\end{abstract}

Keywords: Capstones Courses; Accounting; Internet; Curriculum Development

\section{INTRODUCTION}

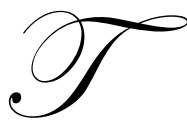

he American Institute of Certified Public Accountants (AICPA) has recently begun promoting an International Financial Reporting Standards (IFRS) certificate program. For \$1,195 AICPA members will receive a comprehensive curriculum consisting of twenty-five online courses. Upon successful completion, members will receive forty-two hours of continuing education credits plus a Certificate of Educational Achievement (AICPA, IFRS Certificate Program). This seems to make sense; perhaps we should make haste to enroll in this or some other IFRS education program, especially if we believe the daily hype, which suggests that the U.S. move to IFRS is a foregone conclusion.

By the end of 2011, the SEC will likely decide on whether to adopt International Financial Reporting Standards as the financial reporting system for U.S. public companies, continue with the convergence project that began in 2002, or reject IFRS altogether. This paper examines the benefits and drawbacks of each option and formulates a recommendation as to which option is in the best interest of U.S. investors.

\section{THE NORWALK AGREEMENT}

On September 18, 2002, the Financial Accounting Standards Board (FASB) and the International Accounting Standards Board (IASB) crafted a memorandum of understanding known as the Norwalk Agreement (FASB, The Norwalk Agreement). In the agreement, both Boards formed a joint commitment to work together for the purpose of developing high-quality accounting standards, suitable for use in domestic and international financial reporting. The plan was to identify differences between GAAP and IFRS, work through these differences to achieve compatibility, issue respective exposure drafts, and revise GAAP and IFRS standards achieving greater (and maybe complete) compatibility. If compatibility could be achieved, then eventual movement to IFRS standards would be relatively painless. Further, since the U.S. is the world's largest economic power, adoption of IFRS would almost guarantee that the rest of the world's financial powers would follow suit.

A noticeable difference between GAAP and IFRS is that IFRS provides less overall detail and industryspecific guidance. Indeed, there has been considerable debate as to which style of standards is preferable: a principles-based style used by the IASB, or a rules-based style used by the FASB. A principles-based system, such as IFRS, provides broad concepts for accountants to follow. Rules or other guidance is kept to a minimum, requiring accountants to use their best judgment in applying the principle. On the other hand, a rules-based system, 
such as GAAP, begins with a conceptual principle and then is embellished over time with guidance for specific situations and/or specific industries. Shortridge and Myring (2004) noted that accounting for leases was addressed in six IASB pronouncements, and addressed in twenty FASB pronouncements, nine FASB Interpretations, ten Technical Bulletins, and thirty-nine Emerging Issues Task Force (EITF) abstracts. And so goes the principles vs. rules debate, with no clear-cut winner. There is probably some middle ground between guidance-heavy GAAP and guidance-light IFRS that would settle this debate.

Since 2002, the agendas of the IASB and FASB Boards have been busy completing an array of short-term and long-term projects, requiring one or both Boards to modify their existing standards. In the April 21, 2011 Progress Report on Convergence Work (FASB, 2011), the Boards identified the following priority projects that are in progress: revenue recognition, leasing, financial instruments, and accounting for insurance contracts. They hope to have all of these projects complete or substantially complete by the end of 2011.

\section{DECISION OPTIONS}

Despite the exhausting convergence efforts of the IASB and the FASB, differences between GAAP and IFRS remain. IFRS prohibits the Last In First Out (LIFO) inventory method. IFRS allows the revaluation of assets in certain circumstances. IFRS uses a single-step for impairment write-downs, as opposed to the two-step method required by GAAP. IFRS requires capitalization of development costs under certain circumstances (AICPA IFRS.com). It seems plausible, given the progress made so far, that these remaining differences will eventually be resolved. The SEC postponed its original target decision date of June 2011, hoping to decide whether or not to adopt IFRS for public companies, continue with convergence, or reject IFRS altogether (FASB, Progress Report) by the end of 2011. We will discuss each option.

\section{Adoption}

The first option available to the SEC is the adoption approach, which is defined here as full use of IFRS as issued by the IASB. This is the ultimate goal of the IASB - one set of common standards used by all multinational companies.

We have identified several benefits to the adoption approach. First, the principle-based approach to setting standards is considered by many to be much simpler, allowing accountants to use a greater degree of judgment in certain situations. Second, financial statement comparisons across country borders would prove much simpler. Third, presentation of financial statements by multinational firms would be greatly simplified by using only one accounting language. Fourth, the use of common standards would increase the mobility of CPAs and other financial professionals. Finally, the use of one common set of accounting standards would improve the quality and reliability of audits and other regulatory procedures.

We see several significant drawbacks to adoption. First, the principles-based approach, used in IFRS, is likely to give headaches to many U.S. accountants, who are used to the rules-based approach used in GAAP. They will struggle with a principles-based approach, fearing that the lack of specific guidance may open the door to subjectivity and variation. Second, an increase in subjective accounting judgment will harm comparability. Third, subjective accounting judgment can leave reporting entities and accountants vulnerable to litigation, which is more of an issue in the litigious Unites States. Finally, and most importantly, the adoption of IFRS will forfeit the oversight authority that the SEC exercises over the FASB, which promulgates GAAP. If adoption were to take place, the SEC would have no oversight authority over the IASB, which promulgates IFRS. As one critic noted, financial reporting issues unique to the U.S. might never be addressed by the IASB if the issues are not problems for the rest of the world (Ciesielski, 2011). If the SEC's mission is to protect the U.S. investor, how is abandoning all oversight authority over financial reporting standards for public companies in the best interest of U. S. investors? We have not seen an answer to this important question. 


\section{Convergence}

Under the convergence approach, countries do not immediately adopt IFRS; instead they maintain local standards, and gradually adjust them to conform to IFRS. The FASB/IASB convergence projects differ somewhat from the typical model just described; many of these projects require movement of both Boards in the formulation of a new standard.

Employing the convergence approach buys time. Business and political organizations often need time to assess the impact of accounting standards changes on their country's economic and political environment. Under the convergence approach, adjustments to accounting standards are transitioned over a time period deemed appropriate by the country's standards setter. Another significant benefit to the convergence approach is that the country, and not the IASB, maintains control over the accounting standards process. Relinquishment of control over accounting standards occurs when and if the country adopts IFRS.

Perhaps the largest disadvantage to the convergence approach is comparability. Each convergence plan has its own timetable, along with a unique set of differences to converge. Comparability across countries is extremely difficult (if not impossible) to achieve.

\section{Rejection}

The United States has the option of rejecting the use of IFRS altogether. As the largest economy in the world, the U.S. has the muscle to make what many might consider a bold move. In doing so, the U.S. would essentially be claiming that after nearly ten years of working jointly with the IASB to bring GAAP and IFRS closer together, GAAP is a better choice for U.S. investors.

Perhaps the greatest benefit in rejecting IFRS is that U.S. accountants can continue using a set of familiar standards. Unfortunately the drawbacks for rejecting IFRS are likely to be significant. In the global political and business environments, the U.S. would surely be viewed as a bully, attempting to impose its will upon the rest of the world.

\section{THE IFRS LANDSCAPE}

More than 120 nations either permit or require IFRS for domestic listed companies (AICPA IFRS.com). It is worthwhile to review the adoption status of the some of the world's largest economic powers. Using GDP as our basis, we selected the following countries for this analysis (Indexmundi, 2011):

\section{Country GDP (Billion \$)}

$\begin{array}{lr}\text { United States } & 14,660 \\ \text { China } & 10,090 \\ \text { Japan } & 4,310 \\ \text { India } & 4,060 \\ \text { Germany } & 2,940 \\ \text { Russia } & 2,223 \\ \text { United Kingdom } & 2,173 \\ \text { Brazil } & 2,172 \\ \text { France } & 2,145 \\ \text { Italy } & 1,774\end{array}$

We used the Pricewaterhouse Coopers LLP IFRS adoption map (IFRS Adoption by Country) as the source for this analysis.

The United States has not adopted IFRS. Foreign private may use IFRS as issued by IASB. Standards used other then GAAP or IFRS must be reconciled back to GAAP. 
China does not use or permit IFRS. China has converged Chinese Accounting Standards (CAS) with IFRS, but differences remain. China plans to continue with convergence.

Japan has chosen the convergence path. Listed companies are permitted to use IFRS as designated by the Financial Services Agency. Foreign companies listed in Japan can use home country's GAAP.

Listed companies in India may use Indian GAAP or IFRS. India's transition to Indian AS (India's version of IFRS with differences) has been deferred.

Germany uses IFRS as adopted by the European Union (EU).

Russia has adopted IFRS, whereby IFRS are translated into the Russian language and given to the Ministry of Finance for adoption. If it is decided that certain provisions of IFRS are not applicable, then such provisions are excluded.

The United Kingdom uses IFRS as adopted by the EU.

Brazil uses IFRS as adopted locally. Certain options allowed in IFRS are not allowed in Brazil.

France uses IFRS as adopted by the EU.

Italy uses IFRS as adopted by the EU.

It is somewhat surprising to learn that none of the top ten economic powers has adopted IFRS as issued by the IASB (and as we defined adoption earlier). Germany, the United Kingdom, France and Italy employ the EU version of IFRS, which from time-to-time excludes and/or delays certain items. This practice is commonly referred to as carve-outs. Russia follows a similar approach. The remaining ten economic powers follow a convergence approach, adjusting their local standards to more closely mirror IFRS.

\section{CONCLUSION AND RECOMMENDATIONS}

Thanks to the joint efforts of the FASB and the IASB, the differences between GAAP and IFRS have diminished considerably. The SEC believes that by the end of 2011 it will be in a position to decide on whether to 1) adopt International Financial Reporting Standards as the financial reporting system for U.S. public companies, 2) continue with the convergence project, or 3) reject IFRS altogether by the end of 2011. We highlighted what we think are the major benefits and drawbacks to each option. Our analysis of the adoption status of the top ten economic powers suggests that the use of a common set of financial reporting standards is still far away. The use of carve-outs hints that the "one size fits all" approach to financial reporting standards might never be achieved, and it might be reason enough for the SEC to reject IFRS. However, we think that rejection of IFRS carries a heavy political penalty and should only be used as a last resort.

We are not in favor of IFRS adoption. As we mentioned earlier, if the SEC's mission is to protect the U.S. investor, how is abandoning all oversight authority over financial reporting standards for public companies in the best interest of U.S. investors? We have not seen an answer to this important question.

Our recommendation is for the SEC to maintain U. S. GAAP and continue along the path of convergence it presently employs. A recent SEC Staff Paper (Work Plan for the Consideration) discussed an option that has come to be known as "condorsement," a variant of the convergence approach, which has some merit. Whatever convergence approach the SEC chooses, oversight control of financial reporting standards for public companies must remain with the SEC.

\section{AUTHOR INFORMATION}

Dr. Clemense Ehoff Jr., CPA, is Assistant Professor of Accounting, Kean University, Union New Jersey. He holds a Ph. D in Business Administration from San Francisco's Golden Gate University. He has more than 30 years professional business experience and has held full-time faculty and adjunct positions at universities predominantly in the Eastern United States. Over the last ten years, Dr. Ehoff has been involved in teaching accounting and tax 
courses in an online platform. He operates a consulting and tax practice. He has published articles in Elevator World, and other journals. E-mail: drehoff@comcast.net. Corresponding author.

Dr. Dov Fischer is Assistant Professor of Accounting, Kean University, Union, New Jersey. He holds a Ph.D. in Business Administration from the University of Colorado at Boulder. His dissertation on investor reaction to news on drug firms won an award from the American Accounting Association. Over the last ten years, Dr. Fischer has taught in universities in New York, British Columbia, and Israel.

\section{REFERENCES}

1. Shortridge, R. T., and Myring, M. (2004) Defining Principles-Based Accounting Standards. Retrieved June 15, 2011 from http://www.nysscpa.org/cpajournal/2004/804/essentials/p34.htm.

2. AICPAIFRS.com. International Financial Reporting Standards: An AICPA Backgrounder (n.d.). Retrieved on June 25, 2011 from http://www.ifrs.com/updates/aicpa/Backgrounder_pdf.html.

3. Ciesielski, J. (2011). I'm Not the Only One Dissing the SEC's IFRS Fixation. The Accounting Onion.

Retrieved July 22, 2011 from http://accountingonion.typepad.com/theaccountingonion/2011/07/im-not-theonly-one-dissing-the-secs-ifrs-fixation.html.

4. Indexmundi. GDP(purchasing power parity) - Country Comparison - Top 10. Retrieved on August 15, 2011 from http://www.indexmundi.com/g/r.aspx?t=10\&v=65\&l=en.

5. Pricewaterhouse Coopers LLP. IFRS Adoption by Country. Retrieved August 10, 2011 from Phttp://www.pwc.com/us/en/issues/ifrs-reporting/country-adoption.

6. FASB. April 21, 2011. Progress Report on IASB-FASB Convergence Work. Retrieved on June 30, 2011 from

http://www.fasb.org/cs/ContentServer?site=FASB\&c=Document_C\&pagename=FASB\%2FDocument_C\% 2FDocumentPage\&cid=1176158460551.

7. FASB. 2002 The Norwalk Agreement. Retrieved June 15, 2011 from http://www.fasb.org/news/memorandum.pdf.

8. $\quad$ AICPA.IFRS Certificate Program, (n.d.) Retrieved August 20, 2011 from http://www.cpa2biz.com/AST/Main/CPA2BIZ_Primary/InternationalAccounting/PRDOVR PC159770/PC-159770.jsp.

9. Staff of the U.S. Securities and Exchange Commission. (May 26, 2011). Work Plan for the Consideration of Incorporating International Financial Reporting Standards into the Financial Reporting System for U.S. Issuers. http://www.sec.gov/spotlight/globalaccountingstandards/ifrs-work-plan-paper-052611.pdf. 
NOTES 